\title{
Systematic and pathologic study of Paratanaisia bragai (Santos, 1934) Freitas, 1959 \\ (Digenea, Eucotylidae) infestation in ruddy ground dove Columbina talpacoti (Temminck, 1811)
}

[Estudo da sistemática e da patologia de Paratanaisia bragai (Santos, 1934) Freitas, 1959 (Digenea, Eucotylidae) em rolinha-caldo-de-feijão, Columbina talpacoti (Temminck, 1811)]

\author{
R.M. Pinto ${ }^{1,3}$, R.C. Menezes ${ }^{1}$, R. Tortelly ${ }^{2}$ \\ ${ }^{1}$ Departamento de Helmintologia - Instituto Oswaldo Cruz \\ Avenida Brasil, n 4365 \\ 21045-900, Rio de Janeiro, RJ \\ ${ }^{2}$ Faculdade de Veterinária da Universidade Federal Fluminense - Niterói, RJ \\ ${ }^{3}$ Bolsista do $\mathrm{CNPq}$
}

\begin{abstract}
This is the first report of the digenetic trematode Paratanaisia bragai infestation in a ruddy ground dove Columbina talpacoti, captured in a suburban area of Rio de Janeiro, Brazil. Although with a low prevalence $(10 \%)$, the intensity of infection was high, considering that 116 worms were recovered from one of the kidneys. Gross lesions were not observed and histopathological analysis showed very dilated renal collecting ducts with destruction and flattening of the lining epithelial cells, without inflammatory reaction. The pathological findings were compared to those previously reported for P. bragai in other hosts, since the proposal of the species in 1934.
\end{abstract}

Keywords: ruddy ground dove, Digenea, Paratanaisia bragai, Columbina talpacoti, pathology, Brazil

\section{RESUMO}

O trematódeo digenético Paratanaisia bragai é referido pela primeira vez parasitando a rolinha-caldo-defeijão, Columbina talpacoti, proveniente de área suburbana do Rio de Janeiro, Brasil. Embora com baixa prevalência (10\%), a intensidade de infecção foi alta, considerando que 116 exemplares do parasito foram obtidos de um dos rins. Não foram observadas lesões macroscópicas. A análise histopatológica demonstrou grande dilatação dos dutos coletores renais, com destruição e achatamento das células epiteliais de revestimento, sem reação inflamatória. Os achados patológicos foram comparados aos anteriormente relatados para P. bragai em outros hospedeiros, desde a proposição da espécie em 1934.

Palavras-chave: rolinha-caldo-de-feijão, Digenea, Paratanaisia bragai, Columbina talpacoti, patologia, Brasil

Recebido para publicação em 30 de abril de 2003

Recebido para publicação, após modificações, em 5 de setembro de 2003

E-mail: rmpinto@ioc.fiocruz.br 


\section{INTRODUCTION}

The ruddy ground dove, Columbina talpacoti Temminck, 1811 is commonly distributed from the southeastern of Mexico, to Meridional Cisandine America (also accidentally in Chile), from the Guyanas to the north of Argentina (including the Tucumán and Buenos Aires provinces), east of Peru, Bolivia, Paraguay, Uruguay (rarely) and Brazil (all the States), except for occasional reports of its presence in the surroundings of these prevailing areas (Pinto, 1978; Sick, 2001).

This bird has often been investigated for ecto and endoparasites, since the species is adapted either to wild or urban environmental conditions, commonly sharing food with sparrows and pigeons in the cities, in residential areas and mainly in the vicinities of pet shops, where captive exotic birds and small rodents are maintained for sale; thus, with the possibility of acting as reservoirs and carriers of pathogenic agents mainly to Galliformes hosts from backyard flocks or other avian hosts of economic importance, specimens of C. talpacoti are referred in surveys of acari ( Arzua and BarrosBattesti, 1999; Price et al., 1999) protozoa (Adriano et al., 2000; Adriano and Cordeiro, 2001 ) viruses (Ferreira et al.; 1994; Pereira et al., 2001) and helminths, that are the main target of this investigation.

Records of worms parasitizing the ruddy ground dove are few and only from Brazil, except for the description of the intestinal trichostrongyloid nematode Ornithostrongylus cristatus DuretteDesset \& Vaucher, 2001, from Paraguay (Durette-Desset and Vaucher, 2001).

The helminths recovered from this host refer to the nematodes Ascaridia magalhaesi Travassos, 1913, Ornithostrongylus magalhaesi Travassos, 1941 from the intestine (Vicente et al., 1995) and the digeneans Brachylaemus (Mazzantia) mazzantii (Travassos, 1927) Travassos \& Kohn, 1964, from the intestine and Tanaisia magnicolica Freitas, 1951 from the kidney (Queiróz, 1966; Travassos et al., 1969).

This paper reports the first occurrence and pathology of the digenean Paratanaisia bragai (Santos, 1934) Freitas, 1959, in the kidneys of Columbina talpacoti.

\section{MATERIALS AND METHODS}

In September, 1966, 10 specimens of the ruddy ground dove were trapped in a suburban area of Rio de Janeiro, RJ, Brazil and further investigated for helminths, according to the files available at the Helminthological Collection of the Oswaldo Cruz Institute (CHIOC) where the deposited compressed/uncompressed samples were maintained in formalin as unidentified material. Helminths were counted and some were stained with carmine, dehydrated in an alcoholic series, cleared with phenol and kept as whole mounts in beechwood creosote and balsam. Fragments of organs were routinely processed for paraffin embedding. Five micrometers thick sections were stained with haematoxylin and eosin. Whole mounts of the worms and histological sections were registered under the number CHIOC 35043 a-i. Slides 35043 a-h contain helminths and the slide 35043 i keeps the histological sections. Photomicrographs were obtained either in a brightfield Olympus Axiophot microscope or in a Leica stereomicroscope. Classification of the helminths follows Freitas (1959), Travassos et al. (1969) and that of the host and its common name are in accordance with Pinto (1978), Frisch (1981) and Sick (2001).

\section{RESULTS}

Helminths were present only in the kidneys of one specimen of Columbina talpacoti, out of the 10 euthanised (prevalence of $10 \%$ ) and 116 worms were recovered from one of the kidneys, $1.5 \mathrm{~cm}$ long, $0.6 \mathrm{~cm}$ wide (the other was used for histopathological analysis) and identified to the digenean Paratanaisia bragai (Santos, 1934) Freitas, 1959, on the basis of specific morphological characters (Fig. 1).

The compressed specimens were $2.6-3.2 \mathrm{~mm}$ in length and $0.51-0.66 \mathrm{~mm}$ in width, with eggs $0.032-0.040 \mathrm{~mm}$ long $\times 0.014-0.018 \mathrm{~mm}$ wide (measurements based on 10 specimens); the uncompressed trematodes were $1.76-2.040 \mathrm{~mm}$ long and $0.51-0.57 \mathrm{~mm}$ wide. The size of the eggs did not vary in uncompressed specimens (measurements based on 10 individuals).

Data on the gross (Fig. 2, 3) and microscopic (Fig. 4, 5, 6) lesions observed were compared to those previously reported (Tab. 1). 


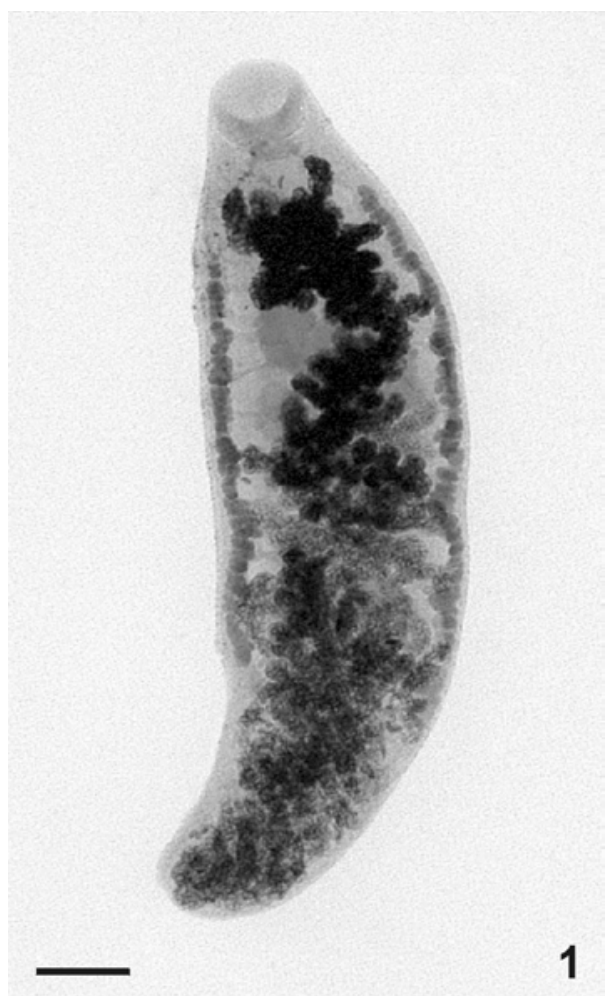

Figure 1. Uncompressed specimen of P. bragai from C. talpacoti, total. Bar $=0.2 \mathrm{~mm}$.

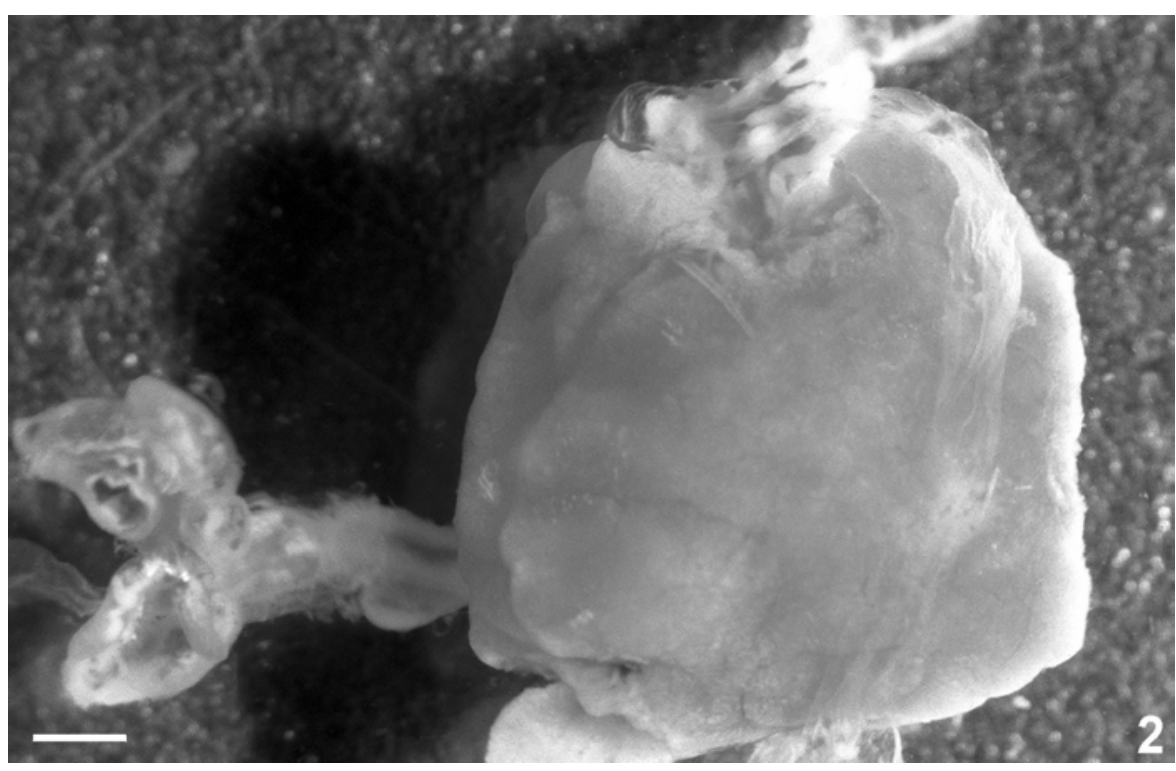

Figure 2. Kidney fragment of $C$. talpacoti parasitized with $P$. bragai showing very dilated collecting ducts with parasites. HE. Bar $=0.5 \mathrm{~mm}$. 


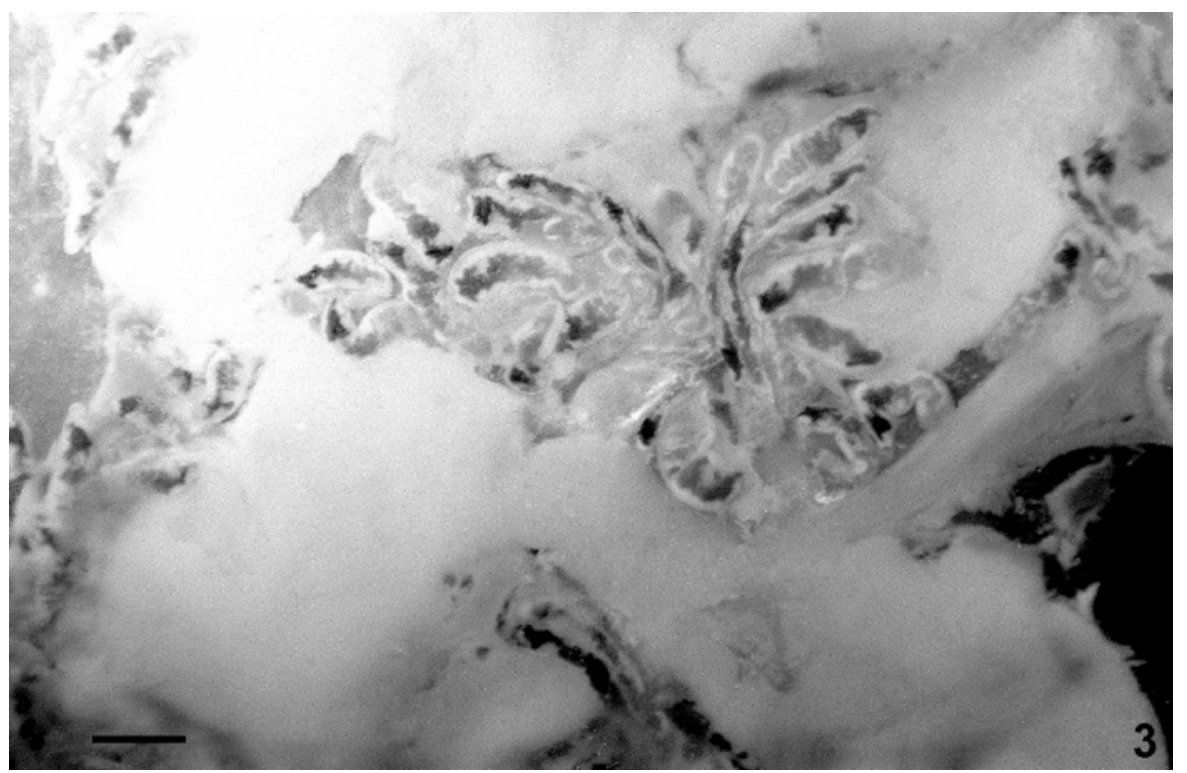

Figure 3. Massive infection by $P$. bragai in a compressed kidney fragment from C. talpacoti. Bar = $0.5 \mathrm{~mm}$.

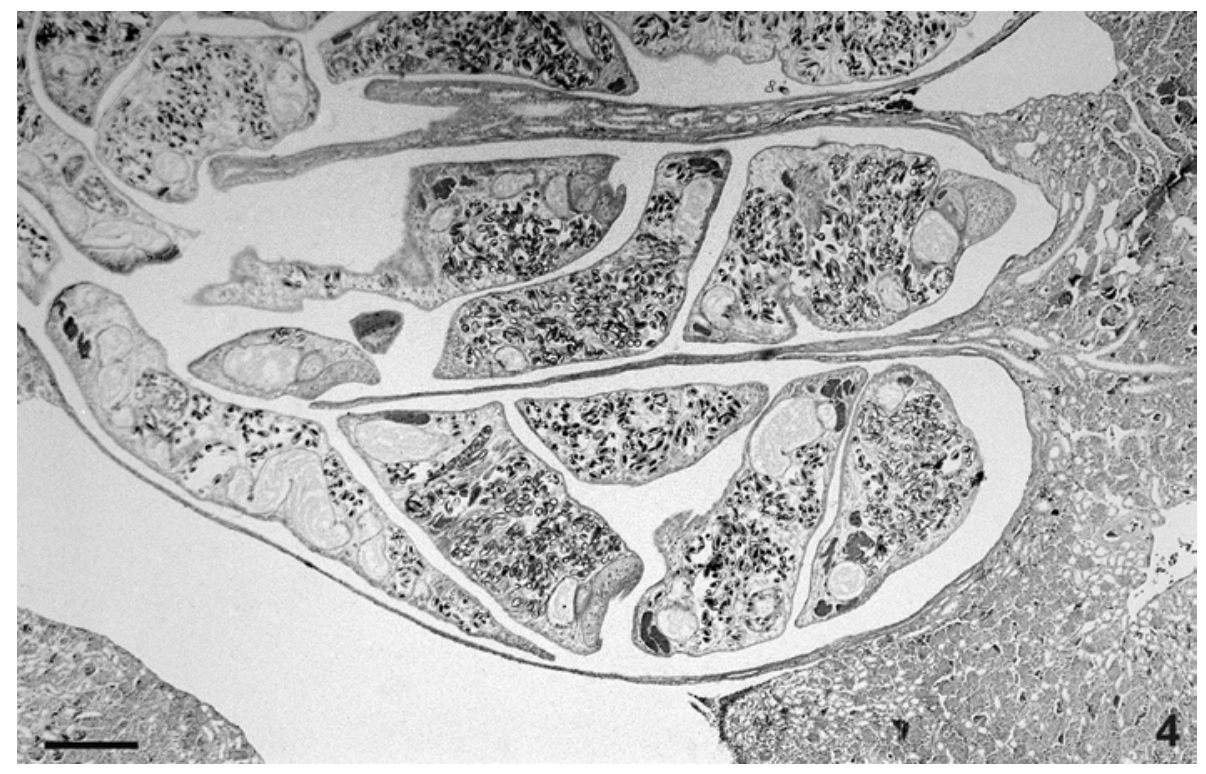

Figure 4. Cross-section of kidney of C. talpacoti parasitized with P. bragai. Very dilated medullary collecting ducts with trematodes. The histology of renal cortex is normal and no inflammatory reaction is observed. HE. Bar $=0.2 \mathrm{~mm}$. 


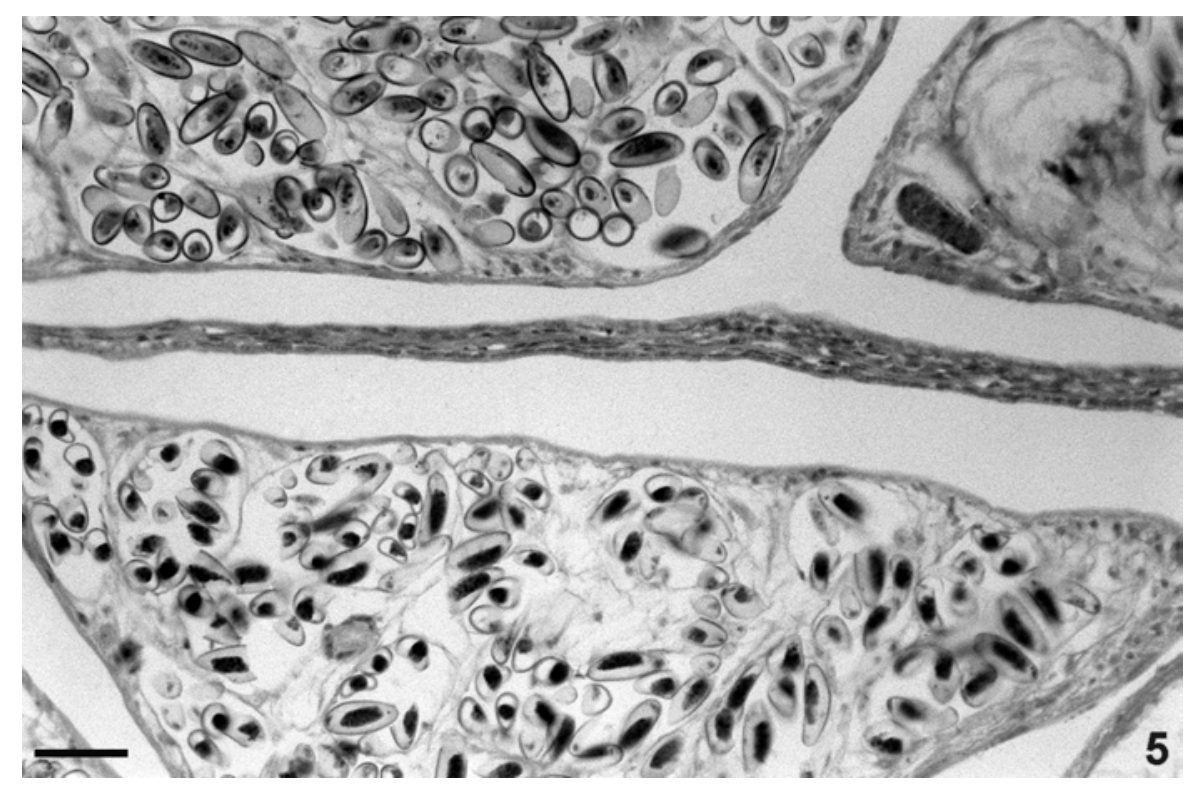

Figure 5. Cross-section of kidney of $C$. talpacoti parasitized with P. bragai. Detail of parasites in the interior of collecting ducts showing flattening of the lining epithelial cells. HE. Bar $=0.05 \mathrm{~mm}$

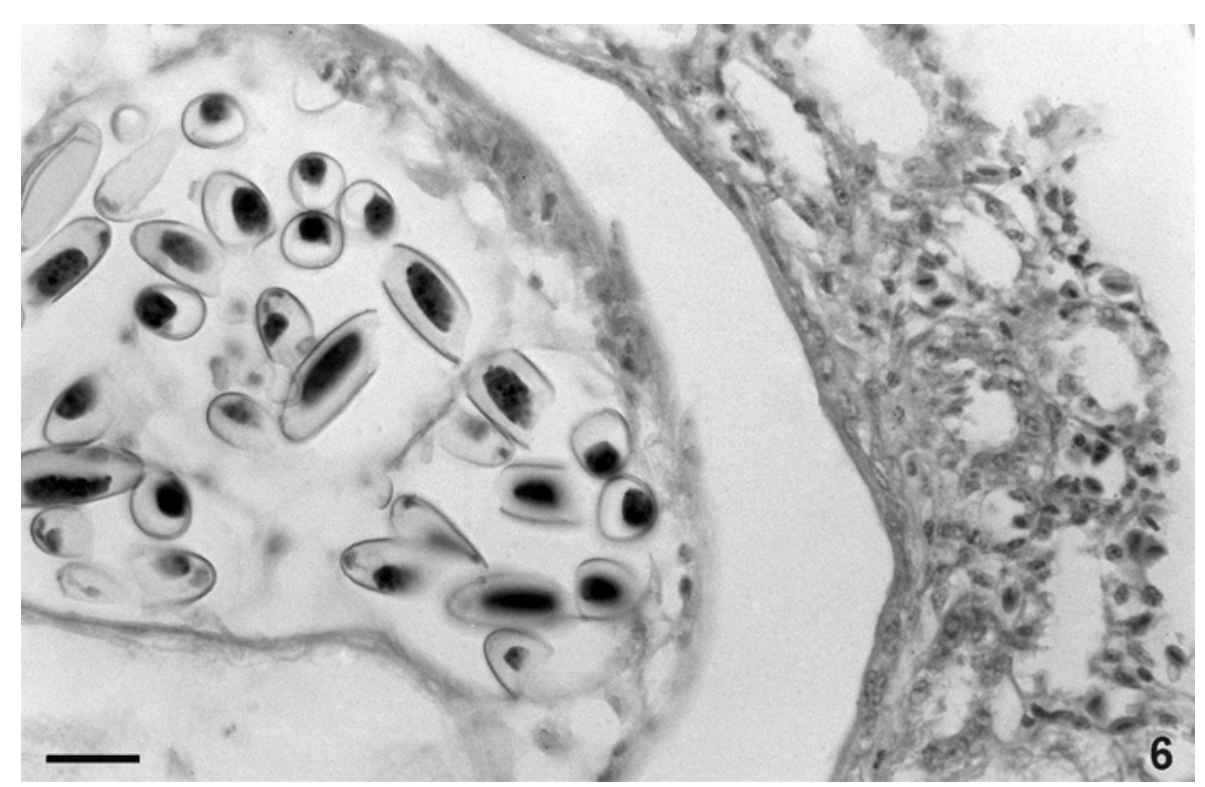

Figure 6. Cross-section of kidney of C. talpacoti parasitized with P. bragai. Detail of a parasite with its tegumentary spines, in the interior of a dilated collecting duct presenting flattening of the lining epithelial cells. No inflammatory reaction in the adjacent renal tissue is observed. HE. Bar $=0.02 \mathrm{~mm}$. 
Systematic and pathologic study...

Table 1. Comparative data on the intensity of infection and pathology of Paratanaisia bragai in the kidneys of different hosts and their distribution

\begin{tabular}{|c|c|c|c|c|c|}
\hline Source & No. of worms & Gross lesions & $\begin{array}{l}\text { Microscopic } \\
\text { lesions }\end{array}$ & Host (s) & Locality \\
\hline Santos (1934) & * & Enlargement & $\begin{array}{l}\text { Dilatation of the } \\
\text { renal collecting } \\
\text { ducts with thick } \\
\text { walls; } \\
\text { multistratified } \\
\text { epithelium and } \\
\text { cellular infiltrate }\end{array}$ & $\begin{array}{c}\text { Columba livia, } \\
\text { Gallus gallus }\end{array}$ & $\begin{array}{c}\text { Rio de Janeiro, } \\
\text { Brazil }\end{array}$ \\
\hline $\begin{array}{l}\text { Barretto and } \\
\text { Filho (1942) }\end{array}$ & ${ }^{*}$ & $\begin{array}{l}\text { Enlargement of } \\
\text { one of the } \\
\text { kidneys; the other } \\
\text { appeared } \\
\text { hypotrophic }\end{array}$ & $\begin{array}{l}\text { Same as above, } \\
\text { except for the } \\
\text { absence of } \\
\text { multistratified } \\
\text { epithelium }\end{array}$ & $\begin{array}{l}\text { Meleagris } \\
\text { gallopavo }\end{array}$ & $\begin{array}{c}\text { Rio de Janeiro, } \\
\text { Brazil }\end{array}$ \\
\hline $\begin{array}{l}\text { Portugal et al. } \\
\text { (1972) }\end{array}$ & ${ }^{* *}$ & $\begin{array}{l}\text { Polycistic, } \\
\text { enlargement and } \\
\text { distortion, } \\
\text { dilatation of } \\
\text { ureters }\end{array}$ & $\begin{array}{l}\text { Parenchymal } \\
\text { cavities with } \\
\text { parasites. No } \\
\text { significative } \\
\text { reactions were } \\
\text { observed }\end{array}$ & Columba livia & $\begin{array}{l}\text { São Paulo, } \\
\text { Brazil }\end{array}$ \\
\hline $\begin{array}{l}\text { Anizaut et al. } \\
\text { (1992) }\end{array}$ & $1,130 * * *$ & $\begin{array}{l}\text { Paleness, } \\
\text { enlargement }\end{array}$ & $\begin{array}{l}\text { Interstitial } \\
\text { infiltrate of } \\
\text { inflammatory } \\
\text { cells within renal } \\
\text { tubules, } \\
\text { composed } \\
\text { primarily of } \\
\text { heterophils and } \\
\text { few eosinophils }\end{array}$ & $\begin{array}{l}\text { Columba } \\
\text { inornata } \\
\text { wetmorei }\end{array}$ & $\begin{array}{l}\text { Humacao, } \\
\text { Puerto Rico }\end{array}$ \\
\hline $\begin{array}{l}\text { Menezes et al. } \\
(2001)\end{array}$ & $1-142 * * * *$ & None & $\begin{array}{l}\text { Chronic } \\
\text { interstitial } \\
\text { nephritis; very } \\
\text { dilated renal } \\
\text { collecting ducts; } \\
\text { sclerosis and } \\
\text { discrete } \\
\text { inflammatory } \\
\text { reaction }\end{array}$ & $\begin{array}{l}\text { Numida } \\
\text { meleagris }\end{array}$ & $\begin{array}{c}\text { Rio de Janeiro, } \\
\text { Brazil }\end{array}$ \\
\hline Present study & $116^{* * * *}$ & None & $\begin{array}{l}\text { Very dilated } \\
\text { renal collecting } \\
\text { ducts with } \\
\text { destruction and } \\
\text { flattening of the } \\
\text { lining epithelial } \\
\text { cells; } \\
\text { inflammatory } \\
\text { reaction absent }\end{array}$ & $\begin{array}{c}\text { Columbina } \\
\text { talpacoti }\end{array}$ & $\begin{array}{c}\text { Rio de Janeiro, } \\
\text { Brazil }\end{array}$ \\
\hline
\end{tabular}




\section{DISCUSSION}

The finding of Paratanaisia bragai in the ruddy ground dove $C$. talpacoti, represents a new host record for the species, previously reported parasitizing kidneys of pigeons, chickens, turkeys, spot-winged quails, guinea fowls (Menezes et al., 2001) and whistling-ducks (Fedynich et al., 1996).

Described as Tamerlania bragai by Santos (1934), included in the genus Tanaisia Skrjabin, 1924 by Freitas (1951) and further reconsidered as Paratanaisia bragai, its actual and accepted nomination, by Freitas (1959) that also erected the genus Paratanaisia, with $P$. bragai as the type, the species is frequently referred in avian pathology surveys; the morphology and life cycle of this digenean have been exhaustively described to add new data on morphometrics and mainly on intermediate hosts, that are terrestrial snails of the species Subulina octona Bruguière, 1789 and Leptinaria unilamellata Orbigny, 1835 (Stunkard, 1945; Silva and Mattos-Júnior, 1990; Arnizaut et al., 1992; Keller and Araújo, 1992).

Although with a low prevalence $(10 \%)$, which was lower than that observed by Silva and Mattos-Júnior (1990) and Menezes et al. (2001) in pigeons and guinea fowls, respectively, from the same state, the intensity of parasitism was high, considering the great number of worms recovered from one of the kidneys only.

The only reference of another digenean, Tanaisia magnicolica, occurring in the kidneys of $C$. talpacoti is that of Queiróz (1966); this species was described by Freitas (1951) on the basis of trematodes recovered from the kidneys of the guira cuckoo Guira guira Gmelin, 1788 and the yellow-billed cardinal Paroaria capitata Lafresnaye \& d'Orbigny, 1837 in Brazil.

The first pathological findings related to $P$. bragai were those reported by Santos (1934) when the species was proposed, on the basis of specimens recovered from the kidneys of pigeons Columba livia (Gmelin, 1798) and chickens Gallus gallus (Linnaeus, 1758) in the state of Rio de Janeiro, Brazil. Other data so far referred on the pathology of the species in other hosts from different localities are those of Barretto and Filho (1942), Portugal et al. (1972), Anizaut et al. (1992) and Menezes et al. (2001). The severity of the microscopic lesions induced by the presence of $P$. bragai seems not to be related to the size of the worm burden, demonstrating a low pathogenicity of this fluke, in despite of the host species. Nevertheless, an outbreak of very high parasite loads can be responsible for the development of the renal monostomosis with mucoid blood diarrhea, mortality and the appearance of gross lesions (Anizaut et al., 1992). Moreover, even when the size of the burden is not mentioned the appearance of the gross lesions seems to be associated to a higher parasite load than that observed by Menezes et al. (2001).

The high degree of mechanical obstruction of the renal collecting ducts observed, induced the presence of trematodes did not stimulate the formation of cysts in the renal parenchyma due to urinary retention. Probably, the great dilatation of the ducts was compensatory, allowing the urine flow. Nevertheless, this dilatation, unexpectedly, did not provoke fibrosis by compression of the adjacent renal tissue. The discrete or absent inflammatory reactions previously reported (Table 1) indicate that the tissular attrition caused by this parasite is minimal, in spite of the presence of the tegumentary spines.

\section{ACKNOWLEDGMENTS}

To Dr Dely Noronha, Curator of the Helminthological Collection of the Oswaldo Cruz Institute (CHIOC) for the access to the samples presently studied; to Dr Luis Cláudio Muniz Pereira, Department of Helminthology, Oswaldo Cruz Institute, for the supply of the reprint after Barretto \& Filho (1942).

\section{REFERENCES}

ADRIANO, E.A.; CORDEIRO, N.S. Prevalence and intensity of Haemoproteus columbae in three species of wild doves from Brazil. Mem. Inst. Oswaldo Cruz, v.96, p.175-178, 2001.

ADRIANO, E.A.; THYSSEN, P.J.; CORDEIRO, N.S. Eimeria curvata n. sp. (Apicomplexa: Eimeriidae) in Columbina talpacoti and Scardafela squamata (Aves: Columbidae) from Brazil. Mem. Inst. Oswaldo Cruz, v.95, p.53-55, 2000. 
ARNIZAUT, A.B.; HAYES, G.D.; OLSEN, H. et al. An epizootic of Tanaisia bragai in a captive population of Puerto Rican plain pigeon (Columba inornata wetmorei). Ann. N.Y. Acad. Sci., v.653, p.202-205, 1992.

ARZUA, M.; BARROS-BATTESTI, D.M. Parasitism of Ixodes (Multidentatus) auritulus Neumann (Acari: Ixodidae) on birds from the city of Curitiba, State of Paraná, Southern Brazil. Mem. Inst. Oswaldo Cruz, v.94, p.597-603, 1999.

BARRETTO, J.F.; FILHO, A.M. Primeiras observações sobre a presença de "Tamerlanea Bragai" (Violantino Santos, 1934) nos rins de Meleagris gallopavo domestica. Rio de Janeiro. Ministério da Agricultura / Instituto de Biologia Animal, 1942. 3p.

DURETTE-DESSET, M.C.; VAUCHER, C. Ornithostrongylus cristatus sp. n. (Nematoda, Trichostrongylina, Molineoidea), parasite de Columbigallina talpacoti (Temm., 1811) (Aves, Columbidae) au Paraguay. Rev. Suisse Zool., v.108, p.291-302, 2001.

FEDYNICH, A.M.; PENCE, D.B.; BERGAN, J.F. Helminth community structure and pattern in sympatric populations of black-bellied and fulvous whistling-ducks. Can. J. Zool., v.74, p.2219-2225, 1996.

FERREIRA, I.B.; PEREIRA, L.E.; ROCCO, I.M. et al. Surveillance of arbovirus infections in the Atlantic forest region, State of São Paulo, Brazil. I. Detection of hemagglutination-inhibiting antibodies in wild birds between 1978 and 1990. Rev. Inst. Med. Trop. São Paulo, v.36, p.265-274, 1994

FREITAS, J.F.T. Nota sobre Tanaisia inopina Freitas, 1951 (Trematoda, Eucotylidae). Atas Soc. Biol. Rio Janeiro, v.3, p.2-4, 1959.

FREITAS, J.F.T. Revisão da família Eucotylidae Skrjabin, 1924 (Trematoda). Mem. Inst. Oswaldo Cruz, v.49, p.33-123, 1951.

FRISCH, D. Aves brasileiras. São Paulo: DalgasEcoltec Ecologia Técnica e Comércio, 1981. 353p.

KELLER, D.G.; ARAUJO, J.L.B. Ciclo evolutivo de Paratanaisia bragai (Santos, 1934) (Trematoda, Eucotylidae) com novo hospedeiro intermediário no Brasil: Leptinaria unilamellata (d'Orbigny, 1835) (Gastropoda, Pulmonata, Subulinidae) em condições de laboratório. Rev. Bras. Med. Vet., v.1/2, p. 89-92, 1992.
MENEZES, R.C.; MATTOS JR, D.G.; TORTELLY, R. et al. Trematodes of free range reared guinea fowls (Numida meleagris Linnaeus, 1758) in the state of Rio de Janeiro, Brazil: morphology and pathology. Avian Pathol., v.30, p.209-214, 2001

PEREIRA, L.E.; SUSUKI, A.; COIMBRA, T.L.M. et al. Arbovirus Ilhéus em aves silvestres (Sporophila caerulens e Molothrus bonariensis). Rev. Saúde Pública, v.35, p.119-123, 2001.

PINTO, O.M.O. Novo catálogo das aves do Brasil. São Paulo: Revista dos Tribunais, 1978. 446p.

PORTUGAL, M.A.S.C.; OLIVEIRA, G.F.; FENERICH, F.L. et al. Ocorrência de Paratanaisia bragai (Santos, 1934) Freitas, 1959 (Trematoda, Eucotylidae), em pomba doméstica (Columba livia domestica). Arq. Inst. Biol. São Paulo, v.39, p.189194, 1972.

PRICE, R.D.; CLAYTON, D.H.; HELLENTHAL, R.A. Taxonomic review of Physconelloides (Phthiraptera: Philopteridae) from the Columbiformes (Aves) including descriptions of three new species. $J$. Med. Entomol., v.36, p.195-206, 1999.

QUEIRÓZ, M.A. Ocorrência de Tanaisia magnicolica Freitas, 1951 (Trematoda, Eucotylidae) em rolinha, no Rio de Janeiro. Atas Soc. Biol. Rio de Janeiro, v.10, p.117-118, 1966.

SANTOS, V. Monostomose renal das aves domésticas. Rev. Dep. Nac. Prod. Anim., v.1, p.206211,1934

SICK, H. Ornitologia brasileira. Rio de Janeiro: Nova Fronteira, 2001. 862p.

SILVA, C.C.; MATTOS-JÚNIOR, D.G. Helmintos parasitos de Columba livia (Gm) no Município de São Gonçalo, Rio de Janeiro. Arq. Bras. Med. Vet. Zootec., v.42, p.1-4, 1990.

STUNKARD, H.W. The morphology of Tamerlania bragai dos Santos, 1934. J. Parasitol., v.31, p.301$305,1945$.

TRAVASSOS, L.; FREITAS, J.F.T.; KOHN, A. Trematódeos do Brasil. Mem. Inst. Oswaldo Cruz, v.67, p.1-886, 1969.

VICENTE, J.J; RODRIGUES, H.O.; GOMES, D.C. et al. Nematóides do Brasil. Parte IV: Nematóides de aves. Rev. Bras. Zool., v.12 (Supl. 1), p.1-273, 1995. 